\title{
Zirconium oxide surface passivation of crystalline silicon
}

Yimao Wan, James Bullock, Mark Hettick, Zhaoran Xu, Di Yan, Jun Peng, Ali Javey, and Andres Cuevas

Citation: Appl. Phys. Lett. 112, 201604 (2018); doi: 10.1063/1.5032226

View online: https://doi.org/10.1063/1.5032226

View Table of Contents: http://aip.scitation.org/toc/apl/112/20

Published by the American Institute of Physics

\section{Articles you may be interested in}

$\mathrm{PO}_{\mathrm{X}} / \mathrm{Al}_{2} \mathrm{O}_{3}$ stacks: Highly effective surface passivation of crystalline silicon with a large positive fixed charge Applied Physics Letters 112, 201603 (2018); 10.1063/1.5029460

Poly-crystalline silicon-oxide films as carrier-selective passivating contacts for c-Si solar cells

Applied Physics Letters 112, 193904 (2018); 10.1063/1.5027547

Effective passivation of silicon surfaces by ultrathin atomic-layer deposited niobium oxide Applied Physics Letters 112, 242105 (2018); 10.1063/1.5029346

Hydrogen passivation of poly-Si/SiO $\mathrm{S}_{\mathrm{X}}$ contacts for $\mathrm{Si}$ solar cells using $\mathrm{Al}_{2} \mathrm{O}_{3}$ studied with deuterium Applied Physics Letters 112, 203901 (2018); 10.1063/1.5031118

Carrier-selective interlayer materials for silicon solar cell contacts Journal of Applied Physics 123, 143101 (2018); 10.1063/1.5020056

Highly effective electronic passivation of silicon surfaces by atomic layer deposited hafnium oxide Applied Physics Letters 110, 021602 (2017); 10.1063/1.4973988

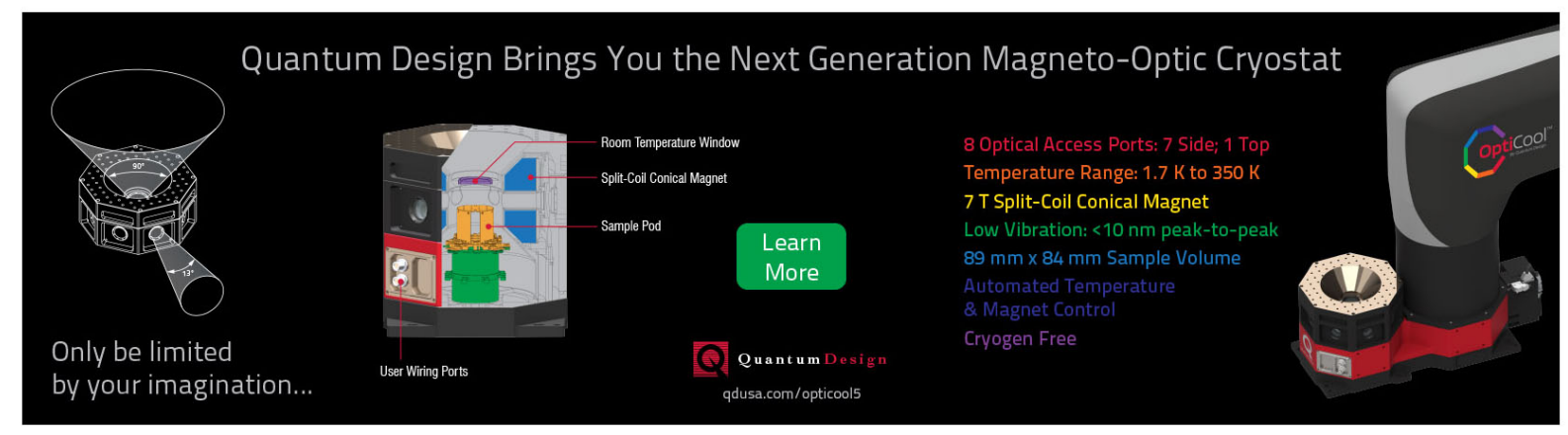




\title{
Zirconium oxide surface passivation of crystalline silicon
}

\author{
Yimao Wan, ${ }^{1,2,3, a)}$ James Bullock, ${ }^{2,3}$ Mark Hettick, ${ }^{2,3}$ Zhaoran Xu, ${ }^{2,3}$ Di Yan, ${ }^{1}$ Jun Peng, ${ }^{1}$ \\ Ali Javey, ${ }^{2,3}$ and Andres Cuevas ${ }^{1}$ \\ ${ }^{1}$ Research School of Engineering, The Australian National University, Canberra, ACT 0200, Australia \\ ${ }^{2}$ Department of Electrical Engineering and Computer Sciences, University of California, Berkeley, \\ California 94720, USA \\ ${ }^{3}$ Materials Sciences Division, Lawrence Berkeley National Laboratory, Berkeley, California 94720, USA
}

(Received 3 April 2018; accepted 7 May 2018; published online 18 May 2018)

\begin{abstract}
This letter reports effective passivation of crystalline silicon (c-Si) surfaces by thermal atomic layer deposited zirconium oxide $\left(\mathrm{ZrO}_{\mathrm{x}}\right)$. The optimum layer thickness and activation annealing conditions are determined to be $20 \mathrm{~nm}$ and $300^{\circ} \mathrm{C}$ for $20 \mathrm{~min}$. Cross-sectional transmission electron microscopy imaging shows an approximately $1.6 \mathrm{~nm}$ thick $\mathrm{SiO}_{\mathrm{x}}$ interfacial layer underneath an $18 \mathrm{~nm} \mathrm{ZrO}_{\mathrm{x}}$ layer, consistent with ellipsometry measurements $(\sim 20 \mathrm{~nm})$. Capacitance-voltage measurements show that the annealed $\mathrm{ZrO}_{\mathrm{x}}$ film features a low interface defect density of $1.0 \times 10^{11} \mathrm{~cm}^{-2} \mathrm{eV}^{-1}$ and a low negative film charge density of $-6 \times 10^{10} \mathrm{~cm}^{-2}$. Effective lifetimes of $673 \mu \mathrm{s}$ and $1.1 \mathrm{~ms}$ are achieved on $p$-type and $n$-type $1 \Omega \mathrm{cm}$ undiffused c-Si wafers, respectively, corresponding to an implied open circuit voltage above $720 \mathrm{mV}$ in both cases. The results demonstrate that surface passivation quality provided by $\mathrm{ALD} \mathrm{ZrO}_{\mathrm{x}}$ is consistent with the requirements of high efficiency silicon solar cells. Published by AIP Publishing. https://doi.org/10.1063/1.5032226
\end{abstract}

Crystalline silicon (c-Si) solar cells remain the most successful photovoltaic technology due to a combination of high power conversion efficiency and low manufacturing cost. One of the key enablers in achieving high performance has been the passivation of the dangling bonds usually present on the silicon wafer surfaces. The most extensively explored, and implemented in industry, materials to suppress defectassisted Shockley-Read-Hall (SRH) recombination are thermally grown or plasma deposited thin films of silicon oxide $\left(\mathrm{SiO}_{2}\right),{ }^{1}$ silicon nitride $\left(\mathrm{SiN}_{\mathrm{x}}\right),{ }^{2,3}$ amorphous silicon (a-Si), ${ }^{4}$ and aluminium oxide $\left(\mathrm{Al}_{2} \mathrm{O}_{3}\right){ }^{5,6}$ Recently, a range of transition or post-transition metal oxides have also been demonstrated to provide high quality passivation of silicon surfaces, including titanium oxide, ${ }^{7,8}$ hafnium oxide, ${ }^{9-12}$ gallium oxide, ${ }^{13}$ and tantalum oxide. ${ }^{14,15}$

Zirconium oxide $\left(\mathrm{ZrO}_{\mathrm{x}}\right)$ is another transition metal oxide having high potential to be compatible with photovoltaic applications, as it has reasonable optical properties (i.e., a relatively high refractive index and a negligible absorption in the visible range) to be used as antireflection coating. ${ }^{16} \mathrm{It}$ has also been reported to provide some passivation of titanium oxide surfaces. ${ }^{17}$ In the semiconductor industry, $\mathrm{ZrO}_{\mathrm{x}}$ has been extensively investigated as an alternative to $\mathrm{SiO}_{2}$ as a gate insulator due to its high dielectric constant $(\sim 25)$, insulating properties, and relatively good thermal stability. ${ }^{18-20}$ Indeed, binary alloy systems of $\mathrm{ZrO}_{\mathrm{x}} /$ alumina or $\mathrm{ZrO}_{\mathrm{x}} / \mathrm{yttria}$ have been patented for the antireflection and passivation of silicon surfaces. ${ }^{21,22}$ However, no scientific details have yet been published on such an ability of $\mathrm{ZrO}_{\mathrm{x}}$ to suppress surface recombination in c-Si photovoltaic devices.

In this letter, we present evidence of effective surface passivation of c-Si by $\mathrm{ZrO}_{\mathrm{x}}$ prepared by atomic layer deposition (ALD). The structure, composition, and interfacial characteristics of this passivating layer are examined using cross-sectional

a)yimao.wan@anu.edu.au transmission electron microscopy (TEM) and x-ray photoelectron spectroscopy (XPS). The passivation quality is then evaluated on undiffused $p$-type and $n$-type c-Si wafers. Furthermore, capacitance-voltage $(\mathrm{C}-\mathrm{V})$ measurements and $\mathrm{X}$-ray diffraction (XRD) are undertaken to probe the electronic and crystal properties of $\mathrm{ZrO}_{\mathrm{x}}$ films before and after thermal annealing to elucidate the physical mechanisms underlying the evolution in surface passivation.

The $\mathrm{ZrO}_{\mathrm{x}}$ films were deposited in a thermal ALD system (Cambridge Savannah) using TEMAZ [Tetra(ethylmethylamido) zirconium] as the zirconium precursor, $\mathrm{H}_{2} \mathrm{O}$ as the oxidant, and $\mathrm{N}_{2}$ as the purge gas. The deposition was performed at $150^{\circ} \mathrm{C}$ and had a corresponding rate of $1.33 \AA$ /cycle as measured by ex-situ spectroscopic ellipsometry (J.A. Woollam M2000 ellipsometer) and also was confirmed by the high resolution TEM presented in Fig. 1(a). The cross section of the $\mathrm{ZrO}_{\mathrm{x}}$ film was prepared using a focused ion beam (FIB) liftout technique in a Helios NanoLab 600 DualBeam SEM/FIB system. Note that the film used for TEM is after thermal annealing $\left(300^{\circ} \mathrm{C}\right.$ for $20 \mathrm{~min}$ in air), which is required to activate the passivation capability by $\mathrm{ZrO}_{\mathrm{x}}$. TEM images were taken using a JEOL ARM200F microscope operating at $200 \mathrm{kV}$. As shown in Fig. 1(a), there exists an approximately $1.6 \mathrm{~nm}$ thick interfacial layer and a $\sim 18 \mathrm{~nm}$ thick $\mathrm{ZrO}_{\mathrm{x}}$ layer. The interfacial layer is typically observed for ALD deposited films $s^{5,6}$ and likely resultant from exposure to water during the first few ALD cycles and/or possible reactions between $\mathrm{ZrO}_{x}$ and the c-Si surface. Furthermore, the TEM also reveals that the $\mathrm{ZrO}_{\mathrm{x}}$ film after annealing exhibits partial crystallization, which is validated by the XRD measurements presented in Fig. 1(b).

XRD measurements were performed on $\mathrm{ZrO}_{\mathrm{x}}$ coated single-side polished c-Si wafers, using a PANalytical X'Pert PRO MRD diffractometer with an X-ray parabolic mirror and a parallel plate collimator $\left(0.27^{\circ}\right)$. The diffraction patterns were obtained by $\mathrm{Ni}$-filtered $\mathrm{Cu} \mathrm{Ka}$ radiation and 

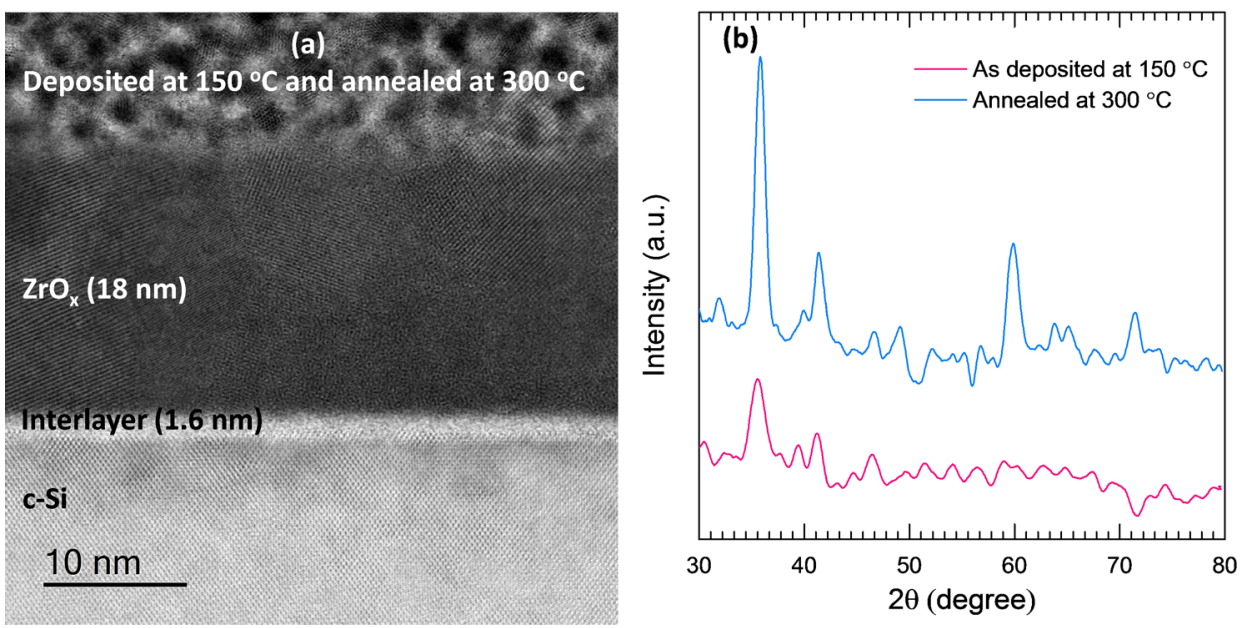

FIG. 1. (a) Cross-sectional TEM image showing an $18 \mathrm{~nm} \mathrm{ZrO}_{\mathrm{x}}$ film with an $\sim 1.6 \mathrm{~nm}$ thick interfacial layer on $\mathrm{c}-\mathrm{Si}$ and (b) XRD features of as-deposited and annealed $\mathrm{ZrO}_{\mathrm{x}}$ films. analysed using the software package MDI Jade. Figure 1(b) plots the XRD pattern of $\mathrm{ZrO}_{\mathrm{x}}$ films as deposited at $150^{\circ} \mathrm{C}$ and annealed at $300^{\circ} \mathrm{C}$. As can be seen, the as-deposited film exhibits very weak diffraction features apart from a peak at $35^{\circ}$, indicating that the film may have some localised crystal nucleation, but is predominantly amorphous. In contrast, the film after thermal annealing shows strong and distinctive diffraction features, consistent with the partial crystallization revealed by TEM in Fig. 1(a).

XPS measurements were performed to determine the stoichiometry of ALD $\mathrm{ZrO}_{\mathrm{x}}$ films before and after annealing. Figure 2 shows the core levels of $\mathrm{Zr} 3 \mathrm{~d}$ and $\mathrm{O} 1 \mathrm{~s}$. While the $\mathrm{Zr} 3 \mathrm{~d}$ spectra show typical doublet peaks located at $182 \mathrm{eV}$ and $184.5 \mathrm{eV}$ for $\mathrm{Zr} 3 \mathrm{~d}_{5 / 2}$ and $\mathrm{Zr} 3 \mathrm{~d}_{3 / 2}$, respectively, the $\mathrm{O} 1 \mathrm{~s}$ spectra can be fitted with two Gaussian components with peaks positioned at $530 \mathrm{eV}$ and $531.5 \mathrm{eV}$, respectively. ${ }^{23,24}$ The small peak located at $531.5 \mathrm{eV}$ is usually attributed to hydroxyl groups although sometimes it can also be due to surface contamination. The component with lower binding energy peaked at $530 \mathrm{eV}$ can be attributed to $\mathrm{Zr}-\mathrm{O}$ binding. Notably, the peak positions for both $\mathrm{Zr} 3 \mathrm{~d}$ and $\mathrm{O}$ 1s are observed to be the similar for the zirconia films before and after thermal annealing. The extracted zirconia film stoichiometry (i.e., $\mathrm{O}$ to $\mathrm{Zr}$ atomic fraction) based on core level peak areas is determined to be 2.0 and 1.8 for the film before and after annealing, respectively, implying that the thermal annealing process makes the film slightly sub-stoichiometric.
To evaluate surface passivation of c-Si by the deposited dielectric, $1 \Omega \mathrm{cm} n$-type and $p$-type c-Si substrates with a thickness of $200 \mu \mathrm{m}$ were symmetrically coated with ALD $\mathrm{ZrO}_{\mathrm{x}}$ films. All wafers were float-zone (FZ) grown and $\{100\}$ oriented. The undiffused wafers were etched in tetramethylammonium hydroxide (TMAH, 25 wt. $\%$ ) at $\sim 85^{\circ} \mathrm{C}$ to remove saw damage. All samples were then cleaned by the RCA (Radio Corporation of America) procedure and dipped in $1 \%$ diluted $\mathrm{HF}$ acid to remove any remaining oxide prior to deposition. The effective carrier lifetime $\tau_{\text {eff }}$ as a function of excess carrier density $\Delta n$ was measured using a Sinton Instruments WCT-120 photoconductance tool. ${ }^{25}$ Neglecting Shockley-Read-Hall recombination in the bulk of the wafer, the upper limit of the effective surface recombination velocity $S_{\text {eff,UL }}$ was calculated according to $S_{\text {eff,UL }}$ $=\frac{W}{2}\left(\frac{1}{\tau_{\text {eff }}}-\frac{1}{\tau_{\text {intrinsic }}}\right)$, where $W$ is the c-Si substrate thickness and $\tau_{\text {intrinsic }}$ is the intrinsic bulk lifetime of c-Si as parameterized by Richter et al. $^{26}$

Figure 3 shows the measured effective lifetime provided by as-deposited and thermally activated $\mathrm{ZrO}_{\mathrm{x}}$ films on $p$-type and $n$-type $1.0 \Omega \mathrm{cm}$ undiffused c-Si wafers. As can be seen, the as-deposited $\mathrm{ZrO}_{\mathrm{x}}$ provides some surface passivation on both $p$-type and $n$-type wafers with a $\tau_{\text {eff }}$ value around $40 \mu$ s at $\Delta n=10^{15} \mathrm{~cm}^{-3}$. Upon thermal annealing at $300^{\circ} \mathrm{C}$ for $20 \mathrm{~min}$ on a hotplate in air, the level of surface passivation is vastly improved by more than one order of magnitude, resulting in
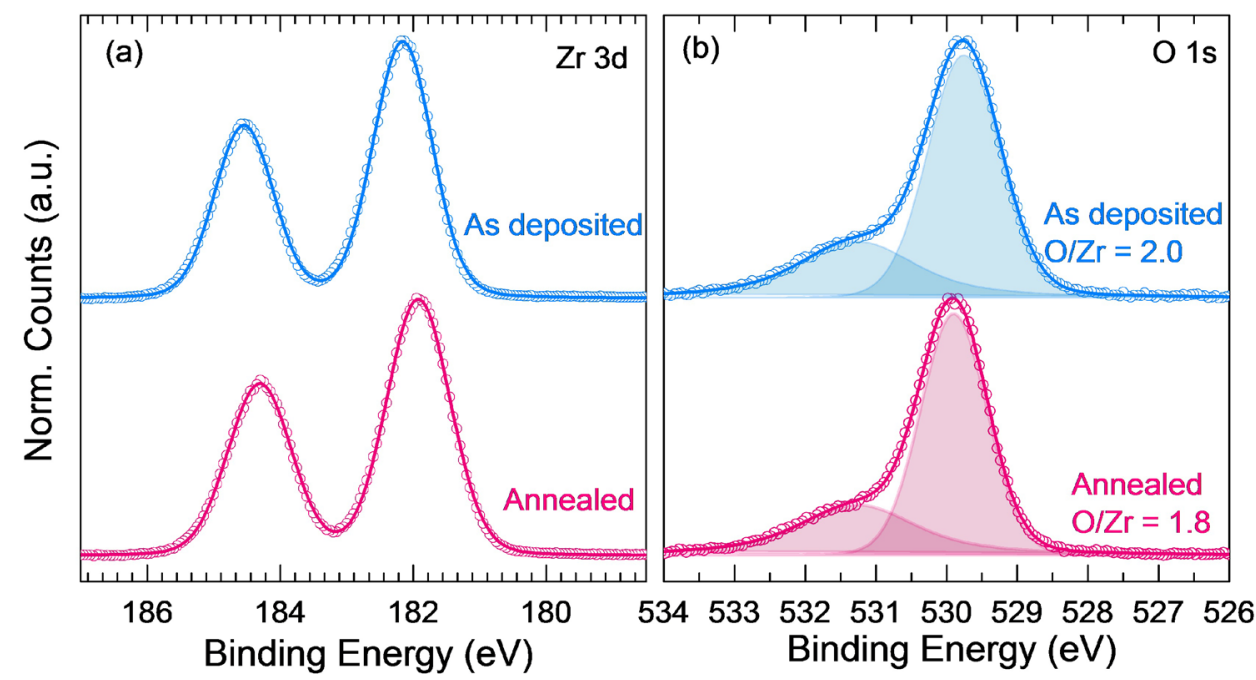

FIG. 2. The core level spectrum of (a) $\mathrm{Zr} \mathrm{3d}$ and (b) $\mathrm{O} 1 \mathrm{~s}$ of as-deposited and annealed $\mathrm{ZrO}_{\mathrm{x}}$ films measured by $\mathrm{X}$-ray photoelectron spectroscopy (XPS) measurements. 


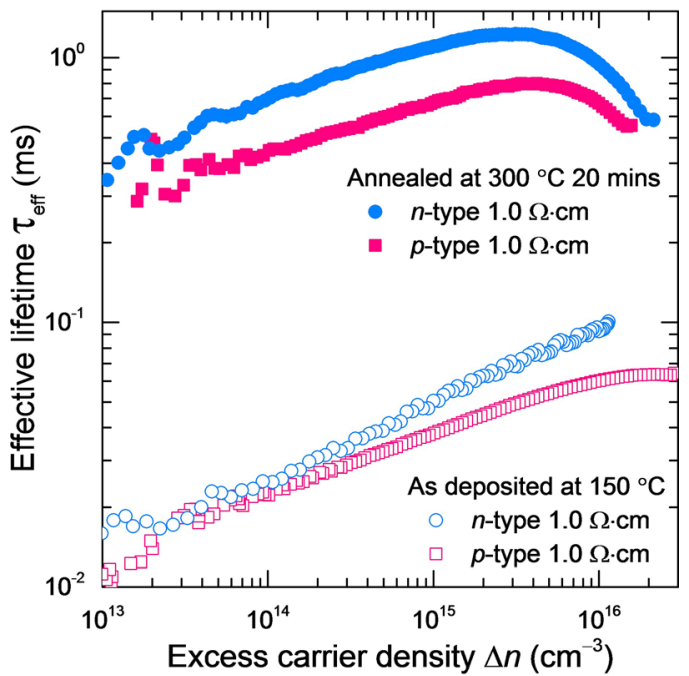

FIG. 3. Effective lifetime $\tau_{\text {eff }}$ as a function of excess carrier density $\Delta n$ for $p$-type and $n$-type $1.0 \Omega \mathrm{cm}$ undiffused $\mathrm{c}-\mathrm{Si}$ wafers passivated by asdeposited and annealed $\mathrm{ZrO}_{\mathrm{x}}$ films.

$\tau_{\text {eff }}$ as high as $673 \mu$ s and $1.1 \mathrm{~ms}$ at $\Delta n=10^{15} \mathrm{~cm}^{-3}$ on $p$-type and $n$-type c-Si, respectively. These lifetimes correspond to $S_{\text {eff,UL }}$ values of $13 \mathrm{~cm} / \mathrm{s}$ and $8 \mathrm{~cm} / \mathrm{s}$ and to implied open circuit voltages of $721 \mathrm{mV}$ and $726 \mathrm{mV}$, respectively. The obtained $S_{\text {eff,UL }}$ by $\mathrm{ZrO}_{\mathrm{x}}$ is slightly higher than that by conventional passivation layers such as $\mathrm{SiN}_{\mathrm{x}}$ or $\mathrm{Al}_{2} \mathrm{O}_{3}$ and comparable to that by $\mathrm{HfO}_{2}$, as summarized in Ref. 12 .

$\mathrm{C}-\mathrm{V}$ measurements were performed to evaluate the physical mechanisms for the substantial improvement in surface passivation upon thermal annealing, using a contactless corona charging method (Semilab PV2000A) on the same $n$-type and $p$-type c-Si samples used for the effective lifetime measurements. ${ }^{27}$ The extracted interface defect density $D_{\text {it }}$ and effective film charge density $Q_{\text {eff }}$ are summarised in Table I. The results show that the as-deposited film presents a significant amount of defects at the $\mathrm{ZrO}_{\mathrm{x}} / \mathrm{c}-\mathrm{Si}$ interface of $1.51 \times 10^{12} \mathrm{~cm}^{-2} \mathrm{eV}^{-1}$, which is then drastically reduced by more than one order of magnitude to a level of $1.0 \times 10^{11} \mathrm{~cm}^{-2} \mathrm{eV}^{-1}$ after annealing. The reduction in $D_{\mathrm{it}}$ is commonly ascribed to the hydrogenation of dangling bonds at the dielectric/c-Si interface, for example, for the case of passivation by $\mathrm{SiN}_{\mathrm{x}},{ }^{2,3} \mathrm{a}-\mathrm{Si}^{4},{ }^{4}$ and $\mathrm{Al}_{2} \mathrm{O}_{3}{ }^{5,6}$ This
TABLE I. Interface defect density $D_{\mathrm{it}}$ and effective fixed charge density $Q_{\text {eff }}$ for $\mathrm{ZrO}_{\mathrm{x}}$ films.

\begin{tabular}{lccc}
\hline \hline & $\begin{array}{c}\text { As-deposited } \\
n \text {-type }\end{array}$ & $\begin{array}{c}\text { Annealed } \\
n \text {-type }\end{array}$ & $\begin{array}{c}\text { Annealed } \\
p \text {-type }\end{array}$ \\
\hline$D_{i t}\left(10^{11} \mathrm{~cm}^{-2} \mathrm{eV}^{-1}\right)$ & 15.1 & 1.0 & 1.2 \\
$Q_{\text {eff }}\left(q\left(10^{10} \mathrm{~cm}^{-2}\right)\right.$ & +4.4 & -5.8 & -5.9 \\
\hline \hline
\end{tabular}

could also be the case for $\mathrm{ZrO}_{\mathrm{x}}$ passivation since the precursor is a hydrogen-containing organometallic compound. The effective charge density is at the order of $10^{10} \mathrm{~cm}^{-2}$ for both asdeposited and annealed samples, which is low compared to the charge density typically found in conventional silicon nitride or alumina films (i.e., $\sim 10^{12} \mathrm{~cm}^{-2}$ ). ${ }^{28,29}$ The thermal annealing switched the charge from positive $4.4 \times 10^{10} \mathrm{~cm}^{-2}$ to negative $5.8 \times 10^{10} \mathrm{~cm}^{-2}$. The cause of the charge polarity change is still under investigation. Consistent results were obtained on both $n$-type and $p$-type substrates. Nevertheless, the substantial improvement in surface passivation by $\mathrm{ZrO}_{\mathrm{x}}$ upon thermal annealing appears to be primarily attributable to a reduction in the interface defect density rather than to an increase in charge density since $Q_{\text {eff }}$ is reasonably low.

The passivation quality by $\mathrm{ZrO}_{\mathrm{x}}$ is shown in Fig. 4 to exhibit a strong dependence on film thickness, thermal annealing temperature, and time. As the film thickness increases, the effective lifetime first increases sharply and peaks at $20 \mathrm{~nm}$. The passivation seems slightly less effective when $\mathrm{ZrO}_{\mathrm{x}}$ becomes thicker. This thickness dependence is similar to that exhibited by ALD hafnium oxide presented by Cui et al., ${ }^{12}$ presumably due to higher crystallinity of thick films upon thermal annealing. A similar behaviour was observed for the dependence of thermal annealing temperature and time, showing an optimum condition at $300^{\circ} \mathrm{C}$ for $20 \mathrm{~min}$. It is worth mentioning that the degradation of passivation upon annealing above $300^{\circ} \mathrm{C}$ could also be due to deterioration of silicon bulk quality, as presented in Ref. 30. As presented before, the thermal annealing activates the passivation by the $\mathrm{ZrO}_{\mathrm{x}}$ film primarily through the reduction in interface defect density. The process window of annealing duration seems reasonably wide between 10 and $30 \mathrm{~min}$. Note that the annealing was conducted on a hotplate in air.

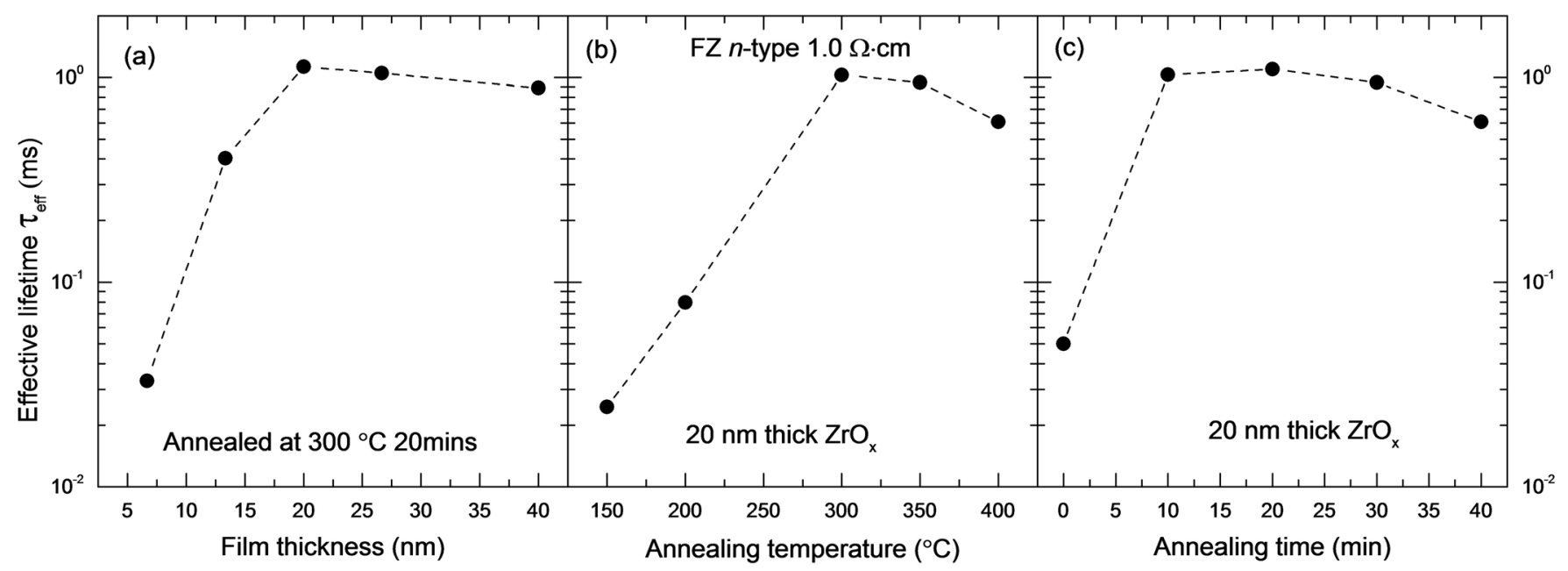

FIG. 4. The dependence of effective lifetime by $\mathrm{ZrO}_{\mathrm{x}}$ passivation on (a) $\mathrm{ZrO}_{\mathrm{x}}$ film thickness, (b) annealing temperature, and (c) annealing time. 
Our preliminary study of annealing in forming gas in the thermal furnace shows similar trends but slightly poorer passivation quality. The reason for this behaviour is still unknown to us and warrants further investigation.

In conclusion, we have shown effective surface passivation of c-Si wafers by thermal $\mathrm{ALD} \mathrm{ZrO}_{\mathrm{x}}$ with an optimum thickness at $20 \mathrm{~nm}$ and annealing at $300^{\circ} \mathrm{C}$ for $20 \mathrm{~min}$ in air ambient. Effective lifetimes of $673 \mu \mathrm{s}$ and $1.1 \mathrm{~ms}$ were achieved on $p$-type and $n$-type $1 \Omega \mathrm{cm}$ undiffused wafers, respectively, corresponding to $S_{\text {eff,UL values of } 13 \mathrm{~cm} / \mathrm{s} \text { and }}$ $8 \mathrm{~cm} / \mathrm{s}$ and an implied $V_{\mathrm{OC}}$ above $720 \mathrm{mV}$. C-V measurements revealed that the annealed $\mathrm{ZrO}_{\mathrm{x}}$ film features a low $D_{\text {it }}$ of $1.0 \times 10^{11} \mathrm{~cm}^{-2} \mathrm{eV}^{-1}$ and a low negative $Q_{\text {eff }}$ of $-6 \times 10^{10} \mathrm{~cm}^{-2}$. The demonstrated high passivation by ALD $\mathrm{ZrO}_{\mathrm{x}}$ paves the way for its application in the design and fabrication of high efficiency silicon solar cells.

We would like to thank Dr. Jason Cui for XRD measurements and analysis and Dr. Ziv Hameiri and Mr. Kyung Kim for contactless corona CV measurements and analysis. This work was supported by the Australian Government through the Australian Research Council (Discovery Project No. DP150104331) and the Australia-U.S. Institute for Advanced Photovoltaics (AUSIAPV) program under Grant No. ACAP6.9. Y.W. holds Individual Fellowship from the Australian Center of Advanced Photovoltaics (ACAP). XPS characterization was performed at the Joint Center for Artificial Photosynthesis, supported through the Office of Science of the U.S. Department of Energy under Award No. DE-SC0004993. Material characterization was supported by the Electronic Materials Programs, funded by the Director, Office of Science, Office of Basic Energy Sciences, Material Sciences and Engineering Division of the U.S. Department of Energy under Contract No. DE-AC02-05CH11231.

${ }^{1}$ M. J. Kerr and A. Cuevas, "Very low bulk and surface recombination in oxidized silicon wafers," Semicond. Sci. Technol. 17(1), 35 (2002).

${ }^{2}$ J. Schmidt and M. Kerr, "Highest-quality surface passivation of lowresistivity p-type silicon using stoichiometric PECVD silicon nitride," Sol. Energy Mater. Sol. Cells 65(1-4), 585 (2001).

${ }^{3}$ Y. Wan, K. R. McIntosh, A. F. Thomson, and A. Cuevas, "Low surface recombination velocity by low-absorption silicon nitride on c-Si," IEEE J. Photovoltaics 3(1), 554 (2013).

${ }^{4} \mathrm{~S}$. De Wolf and M. Kondo, "Abruptness of a-Si:H/c-Si interface revealed by carrier lifetime measurements," Appl. Phys. Lett. 90(4), 042111 (2007).

${ }^{5}$ J. Schmidt, A. Merkle, R. Brendel, B. Hoex, M. C M. van de Sanden, and W. M. M. Kessels, "Surface passivation of high-efficiency silicon solar cells by atomic-layer-deposited $\mathrm{Al}_{2} \mathrm{O}_{3}$," Prog. Photovoltaics: Res. Appl. 16(6), 461 (2008).

${ }^{6}$ B. Hoex, S. B. S. Heil, E. Langereis, M. C. M. van de Sanden, and W. M. M. Kessels, "Ultralow surface recombination of c-Si substrates passivated by plasma-assisted atomic layer deposited $\mathrm{Al}_{2} \mathrm{O}_{3}$," Appl. Phys. Lett. 89(4), 042112 (2006).

${ }^{7}$ A. F. Thomson and K. R. McIntosh, "Light-enhanced surface passivation of $\mathrm{TiO}_{2}$-coated silicon," Prog. Photovoltaics: Res. Appl. 20(3), 343 (2012).

${ }^{8}$ B. Liao, B. Hoex, A. G. Aberle, D. Chi, and C. S. Bhatia, "Excellent c-Si surface passivation by low-temperature atomic layer deposited titanium oxide,” Appl. Phys. Lett. 104(25), 253903 (2014).

${ }^{9}$ G. Dingemans and W. M. M. Kessels, "Aluminum oxide and other ALD materials for Si surface passivation," ECS Trans. 41(2), 293 (2011).
${ }^{10}$ J. Wang, S. S. Mottaghian, and M. F. Baroughi, "Passivation properties of atomic-layer-deposited hafnium and aluminum oxides on $\mathrm{Si}$ surfaces," IEEE Trans. Electron Devices 59(2), 342 (2012).

${ }^{11}$ F. Lin, B. Hoex, Y. H. Koh, J. J. Lin, and A. G. Aberle, "Low-temperature surface passivation of moderately doped crystalline silicon by atomiclayer-deposited hafnium oxide films," Energy Proc. 15(0), 84 (2012).

${ }^{12}$ J. Cui, Y. Wan, Y. Cui, Y. Chen, P. Verlinden, and A. Cuevas, "Highly effective electronic passivation of silicon surfaces by atomic layer deposited hafnium oxide," Appl. Phys. Lett. 110(2), 021602 (2017).

${ }^{13}$ T. G. Allen and A. Cuevas, "Electronic passivation of silicon surfaces by thin films of atomic layer deposited gallium oxide," Appl. Phys. Lett. 105(3), 031601 (2014).

${ }^{14}$ Y. Wan, J. Bullock, and A. Cuevas, "Passivation of c-Si surfaces by ALD tantalum oxide capped with PECVD silicon nitride," Sol. Energy Mater. Sol. Cells 142, 42 (2015).

${ }^{15}$ Y. Wan, J. Bullock, and A. Cuevas, "Tantalum oxide/silicon nitride: A negatively charged surface passivation stack for silicon solar cells," Appl. Phys. Lett. 106(20), 201601 (2015).

${ }^{16}$ R. H. French, S. J. Glass, F. S. Ohuchi, Y. N. Xu, and W. Y. Ching, "Experimental and theoretical determination of the electronic structure and optical properties of three phases of $\mathrm{ZrO}_{2}$," Phys. Rev. B 49(8), 5133 (1994).

${ }^{17}$ M. Vasilopoulou, D. G. Georgiadou, A. Soultati, N. Boukos, S. Gardelis, L. C. Palilis, M. Fakis, G. Skoulatakis, S. Kennou, M. Botzakaki, S. Georga, C. A. Krontiras, F. Auras, D. Fattakhova-Rohlfing, T. Bein, T. A. Papadopoulos, D. Davazoglou, and P. Argitis, "Atomic-layer-deposited aluminum and zirconium oxides for surface passivation of $\mathrm{TiO}_{2}$ in highefficiency organic photovoltaics," Adv. Energy Mater. 4(15), 1400214 (2014).

${ }^{18}$ A. Javey, H. Kim, M. Brink, Q. Wang, A. Ural, J. Guo, P. McIntyre, P. McEuen, M. Lundstrom, and H. Dai, "High- $\kappa$ dielectrics for advanced carbon-nanotube transistors and logic gates," Nat. Mater. 1, 241 (2002).

${ }^{19}$ C. M. Perkins, B. B. Triplett, P. C. McIntyre, K. C. Saraswat, S. Haukka, and $\mathrm{M}$. Tuominen, "Electrical and materials properties of $\mathrm{ZrO}_{2}$ gate dielectrics grown by atomic layer chemical vapor deposition," Appl. Phys. Lett. 78(16), 2357 (2001).

${ }^{20}$ C. M. Perkins, B. B. Triplett, P. C. McIntyre, K. C. Saraswat, and E. Shero, "Thermal stability of polycrystalline silicon electrodes on $\mathrm{ZrO}_{2}$ gate dielectrics," Appl. Phys. Lett. 81(8), 1417 (2002).

${ }^{21}$ J. M. Hwang, Google patent US20120024336A1 (February 2, 2012).

${ }^{22}$ P. Pathi, R. Kalpana, S. K. Srivastava, C. M. S. Rauthan, and P. K. Singh, Google patent WO2017090059A1 (June 1, 2017).

${ }^{23}$ M. Cassir, F. Goubin, C. Bernay, P. Vernoux, and D. Lincot, "Synthesis of $\mathrm{ZrO}_{2}$ thin films by atomic layer deposition: Growth kinetics, structural and electrical properties," Appl. Surf. Sci. 193(1), 120 (2002).

${ }^{24}$ L. Sygellou, V. Gianneta, N. Xanthopoulos, D. Skarlatos, S. Georga, C. Krontiras, S. Ladas, and S. Kennou, " $\mathrm{ZrO}_{2}$ and $\mathrm{Al}_{2} \mathrm{O}_{3}$ thin films on Ge(100) grown by ALD: An XPS investigation," Surf. Sci. Spectra 18(1), 58 (2011).

${ }^{25}$ R. A. Sinton and A. Cuevas, "Contactless determination of current-voltage characteristics and minority-carrier lifetimes in semiconductors from quasi-steady-state photoconductance data," Appl. Phys. Lett. 69(17), 2510 (1996).

${ }^{26}$ A. Richter, S. W. Glunz, F. Werner, J. Schmidt, and A. Cuevas, "Improved quantitative description of Auger recombination in crystalline silicon,” Phys. Rev. B 86(16), 165202 (2012).

${ }^{27}$ M. Wilson, J. D. Amico, A. Savtchouk, P. Edelman, A. Findlay, L. Jastrzebski, J. Lagowski, K. Kis-Szabo, F. Korsos, A. Toth, A. Pap, R. Kopecek, and K. Peter, paper presented at the 2011 37th IEEE Photovoltaic Specialists Conference, 2011.

${ }^{28}$ A. G. Aberle, "Overview on SiN surface passivation of crystalline silicon solar cells," Sol. Energy Mater Sol. Cells 65(1-4), 239 (2001).

${ }^{29}$ L. E. Black and K. R. McIntosh, "Surface passivation of c-Si by atmospheric pressure chemical vapor deposition of $\mathrm{Al}_{2} \mathrm{O}_{3}$," Appl. Phys. Lett. 100(20), 202107 (2012).

${ }^{30}$ N. E. Grant, V. P. Markevich, J. Mullins, A. R. Peaker, F. Rougieux, and D. Macdonald, "Thermal activation and deactivation of grown-in defects limiting the lifetime of float-zone silicon," Phys. Status Solidi (RRL)-RRL 10(6), 443 (2016). 